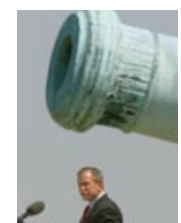

Star wars

Physicists non-

plussed as Bush unveils defence plans p120

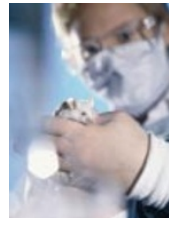

Say cheese Public consortium produces draft mouse sequence p121

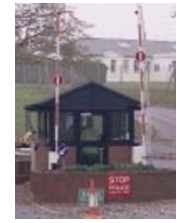

Nerve centre

Britain launches investigation into wartime tests p122

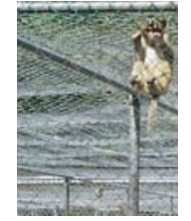
Primate lab Europe ends experiments on chimpanzees p123

\title{
Stem-cell research in doubt as funders clash with government
}

Alison Abbott, Munich

A public clash between Germany's main research funding agency and the government over human embryonic stem-cell research has stalled a decision on the country's first grant application for such work.

The agency, the Deutsche Forschungsgemeinschaft (DFG), announced on 3 May that it was ready to fund human embryonic stem-cell research. But the research ministry, the BMBF, responded immediately with a call for a moratorium on funding individual projects while ethical and moral issues are clarified - setting the stage for a rare confrontation between the supposedly independent DFG and the BMBF, which provides about half of its funding.

As each side paused to consider its position, the DFG's grants committee (which includes BMBF representatives) deferred a decision on the grant to the University of Bonn neuroscientist Oliver Brüstle.

A German embryo protection law forbids creation of stem-cell lines from human embryos for research purposes. But it is not

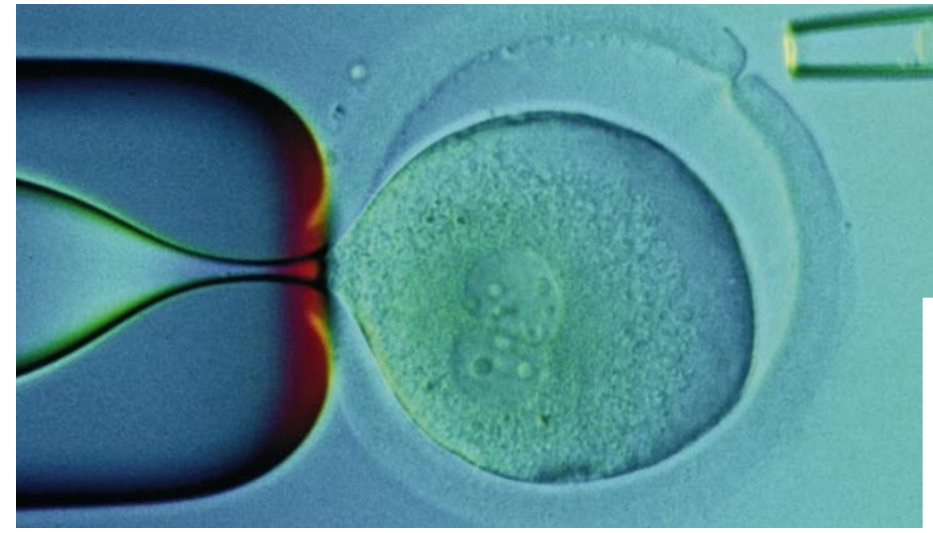

Taking a stand: the DFG's Ernst-Ludwig Winnacker (right) sees no reason why work on imported embryonic stem cells should not receive funding.

illegal to import cell lines for such purposes. Two years ago the DFG published a position statement saying that, given the special sensitivities of German society and how little was known about how embryonic and adult stem cells differentiate into other cell types, German scientists should focus their efforts on

\section{Reprieve for Smithsonian centre}

Corie Lok, Washington

The Smithsonian Institution has abandoned plans to close the National Zoo's

Conservation and Research Center in Front Royal, Virginia (see Nature 410, 727; 2001), after an outcry from conservation biologists and local politicians.

Smithsonian secretary Larry Small, announcing the reversal on 6 May, said the closure plan had been "misinterpreted" by the public as an abandonment of science. He claimed that keeping the centre open was "necessary to correct that false perception".

Small said that the Board of Regents of the museum complex had approved his other plans to restructure museum research and focus it on "centres of excellence". But he announced that a panel of scientists would be set up to advise him on the details of the restructuring. Its members will be drawn from inside and outside the institution.

A subsequent regents' meeting, chaired

by former senator Howard Baker, approved Small's reoganization recommendations in principle and the creation of the panel.

Brian Huber, a palaeobiologist at the National Museum of Natural History and chair of the Smithsonian's academic senate, says Smithsonian researchers "feel pretty targeted" by the restructuring proposal. He wants the panel to look at the whole museum complex, not just at science. "Let's not focus cuts and restructuring just on research," says Huber.

The regents' meeting did approve the closure of the Smithsonian Center for Materials Research and Education, together with the video and audio production facility and two offices at the museum libraries, with the loss of 180 jobs. studying the potential of adult stem cells.

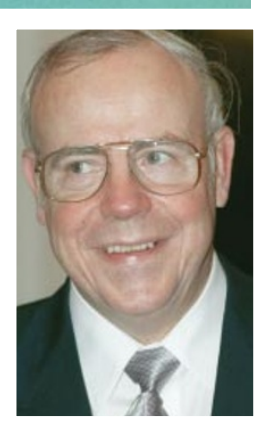

But research has moved much further since then, says Ernst-Ludwig Winnacker, president of the DFG - "and surprisingly fast”. After its senate meeting last Thursday, the DFG issued a new position statement, saying that it now saw "no justification for excluding [from funding] research on imported embryonic stem cells produced legally in other countries." The statement also hints at the need for the embryo protection law to be modified to allow cell lines to be developed in Germany.

The DFG's grants committee, which comprises 19 academic members and 18 representatives from DFG funding organizations, primarily the federal and state governments, met on Friday to discuss funding of applications ranked through peer review. It had been expected to approve Brüstle's application, submitted 10 months ago, to study in vitro differentiation of human embryonic stem cells into neuronal cells, for transplantation into myelin-deficient rats. Deficiency in myelin, the sheath that protects nerves, occurs in multiple sclerosis.

But just after the DFG had announced its new position, research minister Edelgard Bulmahn said that the BMBF "would apply pressure" to defer Brüstle's application.

Winnacker denies experiencing political pressure. "The committee had had no time 
to absorb the conclusions of the senate the night before, and we decided it would only be fair to give the evaluators time to consider the implications," he says. The decision was deferred for two months.

Bulmahn says that Germany's new national ethics council, created last week by Chancellor Gerhard Schröder, should debate the issue of human embryonic stem-cell research. "New courses that cross long-established ethical boundaries, cannot be changed in a hurry," she says.

Wolf-Michael Catenhusen, state secretary for research, says: "The DFG can formulate its position as often as it wants, but this does not change public opinion - nor political opinion."

"It is very appropriate that Germany has approached embryonic stem-cell research slowly and carefully," says Brüstle. But he is surprised and disappointed that his research is still being held up. "The continual delays are starting to feel no different from rejection."

Winnacker declines to speculate on what would happen if the research ministry tried to instruct the DFG - whose independence is enshrined in statute not to fund embryonic stem-cell research. "I don't know," he says. "Political interference is something that has never happened in the 51 years of DFG history, so we have no precedent."

\section{Birthday meeting bemoans low profile of science office}

\section{Steve Nadis, Boston}

It may be 25 years old, but the White House Office of Science and Technology Policy (OSTP) has yet to establish a strong identity in Washington. That was one recurrent theme at a conference held on 1 May to celebrate the OSTP's anniversary.

John Porter, a science advocate and former Illinois congressman, told the meeting that most members of Congress "would be unlikely to have ever heard of the Office of Science and Technology Policy or to know the initials OSTP. They would probably recognize that the president has a science adviser, but few would be able to identify him or her."

Held at the Massachusetts Institute of Technology, the meeting attracted seven former presidential science advisers, including 91-year-old William Golden, who served as the first real science adviser to Harry Truman just after the Second World War. The position persisted in various forms before it was institutionalized in the 1976 law that established the OSTP as a permanent office, the director of which also serves as the president's science adviser.

Porter said that the low visibility of the OSTP placed an even stronger onus on scientists to step forward and make themselves

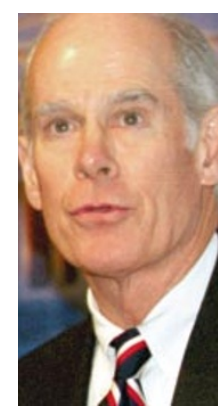

heard in policy debates. MIT president Charles Vest agreed, calling for a new generation of "citizen scientists to explain what we do and why it is important". Changes in education are needed to prepare scientists for this additional role, he said.

Some of the meeting's John Porter says organizers had hoped that scientists need to the new administration of be heard.

President George W. Bush would appoint a science adviser in time for the event, but it did not. Porter noted that Bush has already made decisions on matters such as the Kyoto Protocol and missile defence without input from a presidential science adviser or from the OSTP.

The lack of a science adviser at this stage of the administration is not unprecedented, meeting attendees were told, but it still concerned some of the speakers. Golden said it mattered "because science and technology runs through the fabric of so many issues on both domestic and foreign fronts. Functioning without a science adviser," he said, "is like playing baseball without a full team.”

\section{Plans for missile defence system perturbs physicists}

\section{Irwin Goodwin, Washington}

The announcement by President George W. Bush that he plans to abandon the 1972 AntiBallistic Missile (ABM) treaty has been met with concern from leading US physicists.

The reasoning behind Bush's plan to move ahead rapidly with a new missile defence system for the United States and its allies was questioned by physicists at a recent meeting of the American Physical

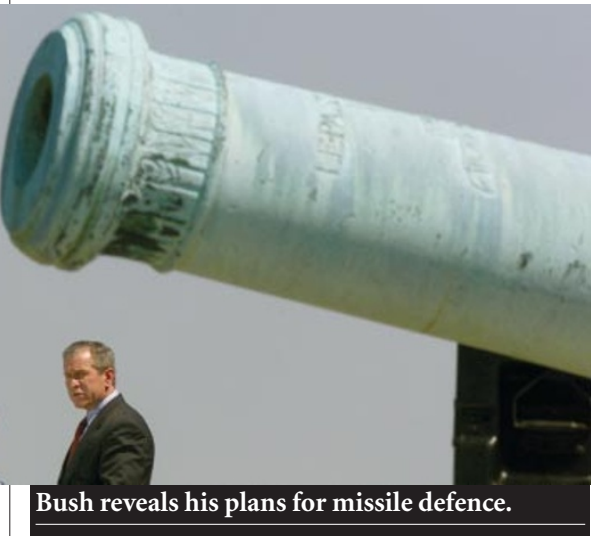

Society (APS) in Washington.

"The last thing the so-called rogue countries would do is launch against the United States, because of the instant retaliation that would result," Richard Garwin, a retired IBM physicist who has advised the US government on $\mathrm{ABM}$ and other technical issues, told the meeting.

Bush has so far offered few details about what his missile defence structure would look like, when it will be deployed or what it would cost. But he has said that the system would be "layered", meaning that it would involve attempts to intercept missiles at each of their flight stages - during launch, in orbit and during re-entry.

Garwin says that the best prospect of a working system is one that targets the missile during its boost phase, as it moves into orbit. The APS has set up a 12-member panel to look into the feasibility of this approach and deliver an unclassified report by the end of the year, in time to feed into Bush's decision on what systems to build.

The Clinton administration's far less ambitious plan called for a smaller system, with 100 missile interceptors based in Alaska and intended to protect against a limited attack by a 'rogue state'. The Congressional Budget Office estimated that Clinton's system would cost about $\$ 60$ billion to deploy.

Some analysts say that the United States has already spent about $\$ 60$ billion on missile defence over the past 50 years, including \$27 billion on President Ronald Reagan's Strategic Defense Initiative, with little to show in return.

Spending on missile defence this year is expected to top $\$ 4.9$ billion, making it the largest single programme in the defence department, even before the programme is expanded to meet Bush's objectives. Critics say that the Bush initiative is likely to cost $\$ 100$ billion or more.

Beneficiaries of the programme may include university scientists in fields such as optics and nanotechnology, but the great bulk of the expenditure will be in development, rather than scientific research, according to officials in the defence department. 